\title{
Helen Kim as New Woman and Collaborator: A Comprehensive Assessment of Korean Collaboration under Japanese Colonial Rule*
}

AhRan Ellie Bae**

\section{Introduction}

In June 2013, the National Institute of Korean History insisted on removing a picture of Helen Kim's statue from history textbooks. ${ }^{1}$ After the 708 pro-Japanese list was published in 2003, students requested that the actual statue at Ewha Womans University be removed from the campus. ${ }^{2}$ The students argued that it was shameful to have a statue of a traitor inside the campus.

The issue of collaboration has been more widely researched and studied in Europe, especially regarding collaboration between occupied countries and Nazi rule during World War II. Novel attempts have been made to examine the issue of collaboration beyond nationalist historiography.

\footnotetext{
* A condensed version of this article was presented at the Association for Asian Studies Annual Conference in Chicago, IL on March 27, 2015.

** $\mathrm{PhD}$ Candidate, Graduate School of Social Design Studies, Rikkyo University

1 Jihoon Kim, "Kyogwasŏ 'ch'in'il' kimhwallan tongsang sajini idae p'yŏmha?," Han'gyŏrye, June 1, 2013, http://www.hani.co.kr/arti/society/schooling/590024.h tml.

2 This list was formulated by Minjokchŏnggirŭl seunŭn Kukhoeŭiwŏnmoim, established by several members from the National Assembly.
} 
For instance, in The Trial of Pierre Laval: Defining Treason, Collaboration and Patriotism in World War II France, J. Kenneth Brody considers Laval's reasons behind his willingness to collaborate with Nazi rule. Nonetheless, according to Patrick Marsh, in the book titled Collaboration in France: Politics and Culture during the Nazi Occupation, "Despite an ever increasing amount of literature on the history of the Second World War in general and of Nazi rule in occupied Europe in particular, there is still no real agreement on the exact meaning of the term "collaboration.",33

In the case of Asia, the issue of collaboration is ensnared with strong nationalistic sentiments, which makes it all the more complicated to pose difficult questions that would inevitably be criticized as being antinationalistic. In the case of Korea, several scholars have suggested colonial modernity as an approach to overcome the binary narrative of nationalist history. ${ }^{4}$ Nonetheless, the issue of collaboration is often inseparable from moral judgments, which proclaim these individuals to be guilty of treason even though they are no longer able to speak for or defend themselves. For instance, Pak Chihyang, in her comprehensive analysis of Yun Ch'iho's diaries, argues that "his involvement in encouraging men to enlist into Japan's imperial army went beyond betraying his own people-it should be treated as a crime against humanity."

Although there is still much debate about what collaboration is and how it should be defined, several definitions of collaboration could be

3 Gerhard Hirschfeld and Patrick Marsh, eds., Collaboration in France: Politics and Culture during the Nazi Occupation, 1940-1944 (Oxford: Berg, 1989), 3.

4 Michael Robinson, Cultural Nationalism in Colonial Korea (Seattle, WA: Univ. of Washington Press, 2014), 48-77, describes intellectuals who experienced colonial modernity head on as cultural nationalists. These intellectuals believed that enlightenment and personal development had to precede political independence. Also see, Gi-Wook Shin and Michael Robinson, eds., Colonial Modernity in Korea (Cambridge: Harvard University Asia Center, 1999) for further discussion on colonial modernity in the Korean context.

5 Jihang Park (Chihyang Pak), Yunch'ihoŭi Hyŏmnyŏgilgi: о̆nŭ Ch'in'il Chisiginŭi Tokpaek (Yun Ch'iho's Collaboration Diaries) (Seoul: Esoope, 2008), 212. 
useful in understanding Korean collaboration with the Japanese colonial government. Timothy Brook follows Henrik Dethlefsen in defining collaboration as "the continuing exercise of power under the pressure produced by the presence of an occupying power." While this definition is useful, Brook points out that it is limited in that this definition is used to describe Denmark's unique history, in which Denmark was allowed to keep and maintain its government under the Nazi occupation. In the case of Korea, Yumi Moon's definition of collaboration as “political engagements of local actors to support a given colonial rule and to justify its sustenance in their society" is more applicable in that it reflects Korea's subordinate position as a colonial subject. In this paper, this particular definition will be used to discuss various issues of collaboration.

Due to the recent accusations regarding ch'in'ilp' $a$ (collaborator), the evaluations of Helen Kim's works has become sharply divided between those who hail her as a pioneer of furthering women's education in Chosŏn and those who vehemently criticize her for her alleged ch 'in'ilp'a actions. Those who praise her argue that she was forced to collaborate with the Japanese; to protect Ewha, she had no other choice. Often, these arguments focus on Helen Kim's many achievements such as her efforts to eradicate illiteracy to initiate rural enlightenment campaigns, and to build a "Korean" Ewha are just a few that are mentioned. ${ }^{7}$ However, these arguments are often based on her personal accounts written decades after the Japanese rule, which requires us to be cautious about their authenticity. ${ }^{8}$

Many criticize her for betraying her people or the Korean race (minjok)

6 Timothy Brook, Collaboration: Japanese Agents and Local Elites in Wartime China (Cambridge: Harvard University Press, 2005), 2.

7 Sung-Eun Kim, "Ilchesigi Kimhwallanŭi Yŏgwŏnŭisikkwa Yŏsŏnggyoyungnon," (Helen Kim's Thought of Women's Right and Korean Women's Education) Yŏksa wa Gyŏnggye (History and the Boundaries) 79 (2011): 184.

8 Jisook Ye, "Ilcheha Kimhwallanŭi Hwaltonggwa Taeil Hyŏmnŏk,"(Kim Hwal Ran's Public Track and Her Pro-Japanese Collaboration during Colonial Korea under Imperial Japanese Reign) Han'guksaron 51 (2005): 398. 
while using the excuse of furthering women's rights. She is accused of succumbing to Japan's demands, giving pro-Japanese speeches in villages, and encouraging women to volunteer as sex slaves for soldiers. ${ }^{9}$ These two clearly binary arguments are based on the sole assumption that what was right for the people equated fighting and even risking one's safety for Chosŏn's independence. This causes one to judge Helen Kim and many other prominent historical figures based on nationalistic moral standards, retrospectively.

Recently there have been more attempts to understand Helen Kim outside of the pro-Japanese versus traitor framework. For example, in "Kim Hwalran's (Helen Kim) Public Track and Her Pro-Japanese Collaboration During Colonial Korea under Imperial Japanese Reign," Ye Jisook portrays Helen Kim as an indigenous intellectual who tried to elevate women and the overall status of Koreans by becoming part of Japan's growing empire. ${ }^{10}$ Also, Kim Jihwa similarly asserts in her dissertation that Helen Kim did not suddenly betray Korea and became pro-Japanese; rather, she had to constantly maneuver between collaboration and negotiation with the Japanese as she devised ways to provide education for Korean women in a rapidly changing society. ${ }^{11}$ These research studies have provided new approaches to the existing paradigm regarding the issue of collaboration. Nonetheless, since these studies are largely limited to a few individuals and their writings, they fall short of providing a more comprehensive analysis of the issue of collaboration in the colonial context.

Specifically, these studies reinforce nationalist historiography's tendency to minimize the importance of gender and how gender shaped one's

9 Yoko Okuyama, "Helen Kim's Life and Thought under the Japanese Colonialism 1918-1945” (MA diss., Yonsei University, 1989), 45-46.

10 Jisook Ye, "Kim Hwal Ran's Public Track," 398.

11 Jihwa Kim, "Kimhwallan'gwa pagindŏkŭl chŭngsimŭro pon Ilche sidae Kidokkyo yŏsŏng Chisiginŭi 'Ch'in'ilchŏk' maengnak yŏn'gu”' (A Study on the Context of 'Pro-Japanese' activities by Christian Intellectual Women under the Japanese Colonial Rule Focused on Helen Kim \& Induk Pahk) (PhD diss., Ewha Womans University, 2005), 115. 
experience in the colonial era. It assumes that loyalty to the minjok should have been absolute, and ultimately, no other priorities could have been more important. This way of thinking hinders us from truly understanding the complex nature of women's identity in the colonial era-specifically, how Korean women were uniquely situated as not only the "lesser" gender but also the colonial subject to be ruled. Korean women of the colonial era had to simultaneously deal with patriarchal oppression and imperialist exploitation. $^{12}$

In this paper, I would like to focus on the following question: Should a divided loyalty and resultant collaboration automatically be treated as treason against the Korean people? As Brook states in his book, Collaboration: Japanese Agents and Local Elites in Wartime China, "Collaboration happened when individuals in real places were forced to deal with each other." 13 Helen Kim, as an educator and as a new woman, was also "forced to" deal with others and makes decisions without the hindsight of knowing where Korea would end up in decades to come.

\section{Accusations}

According to the Pro-Japanese Biographical Dictionary (Ch'in'il Inmyŏng Sajŏn) published on November 8, 2009 by Minjongmunjeyŏn'guso (The Center for Historical Truth and Justice), first and foremost, Kim is accused of beautifying Japan's "war of aggression" and promoting kouminkaseisaku (Japanization). She is criticized for giving "praise" for Japan's war of aggression and urging people to participate in

12 For further discussions on this concept of this "double bind" Korean women experienced, see Pyeongjeon Lee, "Shinnyŏsŏngŭi shingmin ch'ehŏmgwa chajŏnjŏk sosŏl yŏn'gu,'(A Study on Modern Women's Colonial Experience and Autobiographical Novel's) Han'gugŏmunhakyŏn'gu (The Research on Korean Language and Literature) 43 (2004): 225-252. See also Insook Kwon, "The New Women's Movement' in 1920s Korea: Rethinking the Relationship between Imperialism and Women," Gender \& History 10-3 (November 1998): 381-405.

13 Brook, Collaboration: Japanese Agents, 26. 
the war. ${ }^{14}$ Secondly, she is accused of using women's rights movement to rationalize women and families' involvement in the war. Also, She is accused of prioritizing women's rights over the Korean minjok and thus, she committed treason against Korea. ${ }^{15}$ The nationalist historiography leaves no room for us to consider what could have motivated Helen Kim to collaborate with the Japanese. It completely ignores the complex nature of collaboration and women's identity during the colonial era. Often, more than anyone would like to admit, resistance and collaboration could not be easily distinguished from each other.

Another minor accusation is that she was willing to collaborate with the Japanese in order to maintain Ewha. ${ }^{16}$ The imperial government began to have a tighter grip on the schools as the war progressed on and as part of the kouminkaseisaku, shrine visits became mandatory for schools. However, some schools such as Sungshil Secondary School refused to participate in these visits (as a Christian missionary school it believed shrine visits went against its beliefs), and as a consequence, the school was forced to close. Ewha was one of many, which agreed to participate in these shrine visits in order to keep the school open.

According to these accusations, there is no doubt that she collaborated with the Japanese. However, the focus of this paper is not about proving or disproving her involvement with the Japanese. Rather the purpose of this paper is to problematize the fixed notions we associate with the issue of collaboration by examining possible accountabilities for Helen Kim's collaborative actions.

14 Kyŏngro Yun et al., Ch'in 'il inmyŏng sachŏn (Pro-Japanese Biographical Dictionary) (Seoul: Minjok munje yŏn'guso, 2009), 709-714.

15 Yun et al., Ch'in'il inmyŏng sachŏn, 709-714.

16 Yun et al., Ch'in'il inmyŏng sachŏn, 709-714. 


\section{Her Identity as a New Woman and Her Calling as an Educator}

Raised by a devout Christian mother, Helen Kim had a rare opportunity to receive an education, even though education was considered to be "useless" for girls in Chosŏn. She received most of her education through Ewha. Ewha, established in 1886 by Mary F. Scranton who was a Methodist Church missionary, was the first educational institutions for women established in Chosŏn in 1886. After graduating from Ewha, she was able to earn a master's degree in philosophy at Boston University. Also, she was the first Korean woman to receive a doctorate, from Columbia University in 1931.

She possessed many unique qualities associated with "the new woman"-highly educated, economically independent - and was a pioneer of women's rights movement in Korea. However, because of her strong Christian background, she was different from other mainstream female intellectuals, who were often accused of having a promiscuous lifestyle. ${ }^{17}$ She was rarely mentioned in scandals and rumors that pestered other female intellectuals, such as Pak Intǒk. She was an avid educator who believed that many of Chosŏn's ills could be solved through long-term education programs and practical means to improve daily practices. For example, in her doctoral dissertation titled, "Rural Education for the Regeneration of Korea," she suggests that cultural centers should be established in the villages to "keep up the growth of the villagers." 18 She goes on to

17 Christianity played an important role, in that many women were able to gain access to education through schools established by missionaries. It is well known that conflicts intensified between Korean intellectuals and missionaries over time. Thus, even though missionaries were considered pioneers of women's education in Korea, at the same time, they were seen as imposing Western values on Koreans. For further discussion on Christianity and its influence on Christian female intellectuals, see Jihwa Kim, "Kimhwallan'gwa pagindǒkŭl chŭngsimŭro pon Ilche sidae Kidokkyo yŏsŏng Chisiginŭi ‘Ch'in'ilchŏk' maengnak yŏn'gu,' 26-69.

18 Helen Kim, "Rural Education for the Regeneration of Korea," in Uwŏlmunjip, ed. Kim Okkil et al. (Seoul: Ewha Womans University Press, 1979), 132. 
also suggest that a training center should be established so that men and women would have the opportunity to prepare themselves for various vocations.

\section{Accountabilities}

First and foremost, it is crucial for us to free ourselves of the notion that doing what was patriotic for the minjok equaled fighting for Chosŏn's independence. There is a possibility that people did not expect Chosón to become an independent nation in the near future, especially after the March $1^{\text {st }}$ Movement's failure to produce the desired outcome in 1919. Many so-called nationalists were forced to seek other possibilities as the movement disintegrated under pressure and harassment from the colonial government and growing dissonance amongst groups within the movement.

Although Helen Kim is heavily criticized for her activities in the late 1930s and early 1940s, her earlier writings also do not indicate her desire to promote Chosŏn's independence. For Helen Kim, her emphasis constantly remained on women - from relentlessly pursuing education for women to giving practical advice on how to manage household chores. Although many researchers and scholars have argued that 1937 was the year that Helen Kim committed pyŏnjŏl, or betrayed Korea, in reality, many agendas that Helen Kim advocated in her writings in the 1930s and 40s can be traced back to her earlier writings. The idea that she betrayed the people to promote women's rights overlooks how Chosŏn was a maleoriented society deeply rooted in Confucianism. Helen Kim and many other women intellectuals of this era were not fighting against the minjok; rather, they were tirelessly challenging the chauvinistic, male-centered Chosŏn society to give recognition to women as more than mere property that men could own. In an article titled "Rebuilding Korea \& the Role of Women," she argues that "when one sex's responsibility and the im- 
portance of it is undermined, the whole machine becomes paralyzed." 19 She believed that Korea's cultural development depended on the woman's role in the family realm and that it was women's responsibility to build an enthusiastic and culturally developed family. ${ }^{20}$ Therefore, the main concern was not about prioritizing women's rights over Korean people; it was more about prioritizing the most marginalized and discriminated group of Koreans- women.

\section{Women`s Rights versus Staying Loyal to the Minjok}

On a determined quest to conquer the entire Asian continent, Japan did not remain satisfied after it forcefully established the puppet state of Manchukuo in Manchuria in 1931. Japan's unquenchable thirst for a greater empire led to total war between Japan and China in 1937. With the war against China at a stalemate, accompanied by Japan's ballooning ambition to "free" Asian colonies under European nations, its resources rapidly depleted. Consequently, it needed to mobilize all possible labor forces, including its colonial subjects. Japan was desperate enough to hand a gun to its colonial subjects to fight the war for Japan, and to do so, it had to devise ways to persuade Koreans into believing that what they were fighting for was worth dying for.

The colonial government's policy on women experienced a transformation during this period. Korean women had strong emotional ties with their sons (which is not surprising since having a son determined a woman`s status and value in society), making it difficult for Japan to recruit soldiers to fight in the war. Many newspaper articles from this period mentioned worried mothers asking whether their sons would come home alive. Some mothers even wondered about the veracity of a myth, which said that if one thousand people were to sew one of their son's clothes, he

19 Helen Kim, "Rebuilding Korea and the Role of Women," The Korea Mission Field, March, 1931, 87-88.

$20 \mathrm{Kim}$, "Rebuilding Korea and the Role of Women," 87-88. 
would be protected from bullets. ${ }^{21}$ To persuade these distraught mothers, as well as able-bodied young women, Japan had to offer an ideology that transcended traditional values and beliefs that Chosŏn put upon women. These women had to be persuaded to sacrifice what established their identity and legitimacy in the family - their sons. Along with a plethora of slogans, propaganda tactics, and policy changes, Japan accelerated the naisen ittai (Japan and Korea as One Body) process - with the sole purpose of creating submissive imperial subjects out of Koreans.

The process of nationalizing the role of women accelerated in Chosŏn, as Japan's desire for more imperial loyal subjects increased with the everexpanding war. Women, now imperial subjects, had the duty of biologically giving birth to more imperial subjects and educating and grooming these subjects to serve the nation in the future. Women's private sphere, even their wombs, had a higher, more honorable purpose to bear fruit for naisen ittai. ${ }^{22}$ Therefore, raising imperial subjects well and transforming them into dedicated workers for the nation became the proud duty of mothers. ${ }^{23}$ Simultaneously, Japan cunningly politicized love, duty, and the family relations of women for the nation. ${ }^{24}$ This was accomplished by giving meaning and value to what women already did within the household. The domestic realm itself became a battleground where women could participate as citizens of the growing empire. Making sure that they did not waste any resources and that they took care of their family's needs were no longer trivial matters - they directly contributed to the empire's survival. Women's identity no longer remained within the boundary of family as a mother, a wife, a sister, and a daughter; women had a vital mission to support the "holy war."

21 Jisook Ye, “Kim Hwal Ran's Public Track,” 446.

22 Kurashige Shuuzou, "Chiwŏnbyŏng moja e parhanŭn sŏ: kukkayunghŭngŭi mot'aenŭn puinŭi hime chae," Samch'ólli 23 (1940): 26.

23 Oono Teruko, "Chiwŏnbyŏng moja e parhanŭn sŏ: pandobuine kungminŭn kamsa," Samch'ölli 23 (1940): 30.

24 Sheila Miyoshi Jager, "Woman and the Promise of Modernity: Signs of Love for the Nation in Korea," New Literary History 29-1 (Winter 1998): 121-34. 
Scholars and many others who have accused Helen Kim of betraying the people, have argued that she "suddenly turned coat" in 1937, and her activities became treacherously "pro-Japanese." The word used to describe Helen Kim's actions after 1937, pyŏnjŏl, has the nuance of a complete change; one day, she was a patriotic social activist fighting for women`s rights, and the next day, she became a woman who sold her soul to pursue selfish goals. Although her activities did quietly alter after 1937, at the same time, much of what she did and said was a continuation from her earlier days as a female educator and activist. Therefore, we must ask whether many of the so-called ch'in 'il activities and statements were truly new and out of Helen Kim's character. For instance, was the process of nationalizing women`s identity within the domestic realm nonexistent before 1937? Was Helen Kim merely accepting, in a passive way, the colonial government's effort to mobilize women for the war?

The idea that the woman's role in the domestic realm is directly linked to participation in the society is evident in many of Helen Kim's so-called pro-Japanese articles in the late 1930s and 1940s as well as in her earlier writings in the 1920s. Helen Kim and many other female leaders passionately asserted that women can play an important role for the nation. Although women were physically bound to the traditional boundary of the home, their identity transcended this through the nationalization process toward women's identity. Home no longer was a private sphere-it became a public sphere where even women's mundane chores became meaningful.

In 1931, Helen Kim wrote an article titled, "Rebuilding Korea \& the Role of Women." In the article, she passionately argues that it is the women`s duty to develop a "dynamic and cultural family" for Korea:

Secondly, most of Korea`s cultural development and continuation depends on the hands of the women. In order for Korea to greatly develop, despite the discrepancies we see, the families of Korea need to function as free entities. . . . They need to not only continue to develop the old, but also continue with conversation, 
family management, and educate the young adults. ${ }^{25}$

She avidly wrote that women mattered to Korea's future development. For her, family was the smallest unit of a nation and keeping these entities healthy and dynamic was the utmost important factor for its further development. And in her perspective, family matters were no longer private matters, but public matters. In another article in which she discusses the issue of work and women, she asserts that the family is part of the society and taking care of the domestic realm equates to working in the society. ${ }^{26}$ She rebukes the so-called new women for having an attitude represented by the following statement: "Since we are stuck at home we might as well raise the kids and take care of the house!" She implores women to realize that "working" does not necessarily mean that all women have to get a job outside of their home; their primary responsibility and "work" is to develop and maintain the "home." In fact, she argues that chores should actually be considered as work with tangible value. ${ }^{27}$

Therefore, it should not come as a surprise when Helen Kim declares that the economy of the kitchen is equal to the economy of the nation. ${ }^{28}$ Helen Kim declares that the "Women of the East" had their own "Eastern way" of taking care of the household. Phrases such as these reflect Helen Kim's utilization of the Japanese war propaganda, which included slogans, such as "Asia for Asiatics," to promote, shape, and form women's identity in Chosŏn.

Many arguments Helen Kim uses in the so-called ch'in'il articles existed before 1937. This continuation reveals how naisen ittai was a two-way process, where the colonized also defined and shaped how it would unravel itself to its colonial subjects. Conceivably, the problem is not what

25 Helen Kim, "Rebuilding Korea and the Role of Women," The Korea Mission Field, March, 1931, 87-88.

26 Helen Kim “Chigŏpchŏnsŏn'gwa chosŏnnyŏsŏng," Shindonga, September, 1932.

27 Kim "Chigŏpchŏnsŏn'gwa chosǒnnyŏsŏng."

28 Helen Kim, "Puŏk'kyŏngjega kukkagyŏngje," Maeilshinbo, July 6, 1938. 
she discussed - the problem is the purpose of what she discussed. The critics indicted her for "betraying" the Korean people. This betrayal is based on the assumption that she collaborated with "the enemy." In the nationalist narrative, the occupying power, Japan, is pegged as the ultimate enemy or the villain to Koreans; therefore, collaboration becomes the ultimate "crime" against Koreans. This one-dimensional depiction of the occupying power, Japan, as the omnipotent enemy that all Koreans fought against, oversimplifies the complex relationship between Japan and Chosŏn. In particular, Korean women were doubly bound by the patriarchal system of Chosŏn as well as Japan's imperialism. In other words, as much as Korean women were exposed to Japan's oppression, they were exposed to the oppression of Korean men. Therefore, to understand the complex nature of one's identity as the inferior gender and as the colonized subject, it is vital for us to explore how Korean women viewed and interacted with men in the colonial context.

\section{Women versus Men}

First of all, Helen Kim never argued for Korea's immediate independence in any of her articles or statements before 1937. Her doctoral dissertation was solely focused on the topic of rural development within the limits of colonial authority. Even though she mentioned in her biography that she always longed for Chosŏn's independence, ${ }^{29}$ unlike others who opted to go underground or be exiled to other countries to lobby for Korea's independence, she did not choose to do so, and her work reflects this decision. She remained in Chosŏn to work for women whom she had the most compassion for. Her affection toward Korea's nationhood was less palpable.

The national narrative of Korean history depicts Japan to be the only oppressor, aggressor, and usurper of Koreans. However, it should be not-

29 Helen Kim, Kŭ pitsogŭi ch'agŭn saengmyŏng (Seoul: Ewha Womans University Press, 1999), 163. 
ed that many resources related to women indicate something else. The traditional, male-dominated Chosŏn society continued to force women to be subjugated to the structural and systemic violence of the Chosŏn Dynasty well into the 1900s. Japan's colonization of Korea did not change the status quo for women either. They were still considered the "lesser" gender, valued as property or tools to expand Japan's empire. As a result, Korean women had to struggle against not only Korean men but also Japanese men as well.

The way new women began to view "old women" or the "old society" indicates the birth of the women's rights movement in Korea. The advancement of modernization nurtured the first generation of Korean women who received modern education, and many of them began to become vocal about what they believed was debilitating Korean womenthe patriarchal values of the Chosŏn Dynasty. The language, which described the position of women in the gender relationship, consisted of words such as slavery; women were born into the family as a slave, and they continued living as a slave obligated to perform traditional duties. ${ }^{30}$ Women were often described as victims of the society, bound by centuries-old traditions and values. What once was considered to be the norm began to be questioned and scrutinized. For instance, arranged marriage came to represent women's lack of freedom and choice. Many articles in Shinyŏsŏng (New Women) ${ }^{31}$ consisted of girls who complained that they had nowhere else to go after finishing their education. They complained to the editor that the only expectations parents imposed on them were to marry and marry well. A girl from the countryside lamented how even if she went back home she would have nothing to do but be forced into a marriage arranged by her family. ${ }^{32}$ The world outside of the school

30 Many articles from the popular magazine Shinyŏsŏng (新女性) mention how women are merely treated like slaves within the domestic realm.

31 Shinyŏsŏng was the first women's magazine published in Chosŏn by Kaebyŏksa. It discussed a wide range of topics that concerned women, including education, housework, child-reading, dating, marriage, and marital problems. 
boundary was plagued by a centuries-old social system, and unfortunately, modern education could not ensure a different future for many of these women. In this context, it is not surprising that many girls were lulled or manipulated into forced prostitution by an illusion of "career" opportunities offered by brokers.

What is interesting is that prominent magazines, such as Shinyŏsŏng, openly talked about women who became entangled in prostitution. Stories of women from poor families sold into slavery or prostitution were not uncommon in Chosŏn. Often when we deal with the issue of comfort women and comfort stations, we readily target the Japanese military only. Although Japan was heavily involved in the systematic recruitment and management of comfort women, we must also make sure that we do not turn a blind eye toward the fact that abuse of women was nothing new in Chosŏn. What is especially overlooked and must not be ignored is the fact that Korean men were also often involved and sometimes were the initiators of violence committed against Korean women. According to Sarah Soh, Koreans were involved as mediators and pimps to recruit Korean women into comfort stations. ${ }^{33}$ Similar to numerous women's rights movements around the world, the few educated women of Chosorn began to voice strong opinions about the existing violence against women in Chosŏn. They cried out that women were treated as men's slaves; Korean women were forced to endure unspeakable amounts of abuse inflicted upon them by men. ${ }^{34}$ Because of these abuses, women "experienced many more obstacles" than men. ${ }^{35}$

Female novelists revealed the brutality of abuse through novels, which depicted women who were manipulated, exploited, and often violated psychologically and physically. In these novels, women seem to have

32 S. WH, "Sijimman karanŭn pumo," Shinyŏsŏng 1 (1923): 131.

33 Chunghee Sarah Soh, The Comfort Women: Sexual Violence and Postcolonial Memory in Korea and Japan (Chicago: University of Chicago, 2008), 138.

34 SJ, "Puinuntongŭi choryu," Shinyŏsŏng 2 (1923): 433.

35 Yŏn'gusaeng, "Puinŭi chijŏk nŭngnyŏk," Shinyŏsŏng 2 (1923): 533. 
almost close to no contact with Japanese men or women, while many Korean male characters molest, rape, and abuse Korean women for their own pleasure. For example, one of the most common cases mentioned throughout literature, magazines, and newspapers is a factory manager's rampant assaults against female workers. Many factory managers took advantage of their position and molested women of various age groups. Often, managers (both Japanese and Korean) enticed and raped young girls, resulting in unwanted miscarriages, abortions, and stillbirths. ${ }^{36}$ Even at home, abuse against women was common and allowed; the abuse could range from cheating to sexual harassments and, at its worst, repeated rape. In the story Inganmunje (A Human Problem), the main character Sunbi is raped by her own stepfather. However, because she is too ashamed of what happened, she decides to leave home and go to work in a factory without confiding in anyone. ${ }^{37}$ This story illuminates the fact that even though women were victims, society forced them to take the responsibility for the consequences brought on by the abuser. Most women did not have the luxury of a choice regarding their future, except for the few who were successful (who are criticized as pro-Japanese). Furthermore, the general acceptance of abuse against women was certainly not unique to Chosŏn. As early as 1886, the Women's Reform Society of Japan spoke out against the concubine system and prostitution, which were believed to be part of a bigger problem of sexual abuse against Japanese women in and out of the domestic sphere. ${ }^{38}$

Chosŏn society's structural violence against women and its continuation during the colonial period were horrendous. As Soh pointed out, we cannot just point the blame at Japan for taking advantage of Korean

36 Theodore Jun Yoo, The Politics of Gender in Colonial Korea: Education, Labor, and Health, 1910-1945 (Berkeley: University of California, 2008), 136.

37 Gyŏngae Kang, In'ganmunje (Seoul: Dream Sodam, 2001). This story was originally published in the newspaper Tongailbo from September 1934 to December 1934.

38 Sharon L. Sievers, Flowers in Salt: The Beginnings of Feminist Consciousness in Modern Japan (Stanford: Stanford University Press, 1983), 93. 
women; Koreans also need to take responsibility for the perpetuation of a rigid patriarchal system that confined and debased women, denying women the right to choose how they wanted to live. The "biggest perpetrators here are the patriarchal societies of Japan and Korea." $" 39$

In the nationalist context, women are again confined to a specific role that is accepted and promoted by men. A fitting illustration of this would be the ideology of "Good Wife, Wise Mother," which developed in Japan and was later implemented in Chosŏn. For Japan, the meaning was given to women as mothers and wives who were in charge of the smallest unit of the national polity. ${ }^{40}$ The glorification of motherhood further developed as Japan avidly pushed forward its agenda to expand its empire. In other words, because of Japan's pursuit of imperialism, the ideal of motherhood had to also expand to encompass the agenda of not only producing and raising the "sons of Japan" but also "asserting colonial hierarchy, and managing colonized subjects through assimilation." 41 This imperial motherhood is also reflected in the way Japanese women were expected to act toward colonial subjects. Since the colonial subject was thought to be underdeveloped (infant-like), slow, and in need of help to become a proper citizen of Imperial Japan, Japanese women were expected to take them under their motherly wings as well.

The short-story "Manchu Girl" by Koizumi Kikue illustrates a case of "the deployment of imperialist motherhood in the colonial context." The story is about a young Chinese girl named Guiyu who was first hired as a servant for a Japanese couple. The Japanese woman, Koizumi, tries her hardest to embrace Guiyu and teach her the ways of the Japanese,

39 Chizuko Ueno, Nationalism and Gender, trans. Beverley Yamamoto (Melbourne: Trans Pacific, 2004), 128.

40 Chin Chŏngwŏn, Higashiasia no ryousaikenboron: tsukurareta dentou (Tokyo: Keisoshobo, 2006), 32.

41 David C. Earhart, Certain Victory: Images of World War II in the Japanese Media (New York: M.E. Sharpe, 2008), 226-227.

42 Michele Mason and Helen J. S. Lee, Reading Colonial Japan: Text, Context, and Critique (Stanford: Stanford University Press, 2012), 227. 
from mastering the language to wearing kimonos. She represented the idealistic role of Japanese women in the colonial context - a parent figure to the colonial subject who surely needed "guidance" from Japan. Kimberly T. Kono noted that Koizumi's status within the empire was dependent on how well she performed her role as an "imperialist mother."

That is, her recognition as a national subject is contingent upon her successful performance of the officially sanctioned role of motherhood. Her status as a subject of Japan is not preexisting or inherent, but rather is produced through her interactions with Guiyu. Koizumi realized her own identity as a Japanese Citizensubject by means of the very process of educating this girl. ${ }^{43}$

As one can see, the so-called "Good Wife, Wise Mother" was used to maneuver Japanese women to embrace motherhood and be responsible for taking care of imperial subjects, including colonial subjects. The nationalized motherhood was the only legitimate role women could engage in. Similarly, the colonial government's intention was to utilize "Good Wife, Wise Mother" as a qualification to become an imperial woman. ${ }^{44}$ Chosŏn women were to embrace their role as the mother of Chosŏn by biologically reproducing sons and gladly sacrificing their sons for the empire. Korean women were in a more challenging position in that they were oppressed not only by the colonial power but also by Korean patriarchal values.

In addition, male nationalists who advocated education for women in the early 1900s began to shift their view on women's rights by the 1920s; they believed that the new woman's audacious challenge of patriarchy and sexuality could create a debacle for Korean tradition and unity. ${ }^{45}$ This is noteworthy since Korean men as colonial subjects did not have the

43 Mason and Lee, Reading Colonial Japan, 234.

44 Kazue Inoue, Shokuminchi chosŏn no shinjosei (Tokyo: Akashishoten, 2013), 37.

45 Kwon, "The New Women's Movement'," 381. 
right to vote, let alone Korean women. Korean women were still highly uneducated, restricted by their lower status in Korean society, and doubly bound not only by patriarchy but also by the colonial power. Therefore, more than their Japanese counterparts, these women had to learn to tread carefully between the colonial government's demands and their hope to educate Korean women and improve their social condition in an environment where even fellow Koreans were unwilling to express their support.

However, once we closely examine the various articles written by female educators from 1937 to 1945, we can observe that some women's views on "Good Wife, Wise Mother" were slightly different from their inland Japanese or Korean male intellectuals' intentions. In Chosŏn, many women put more emphasis on urging women to be part of the holy war than on motherhood. These educators asserted that women were able to contribute and participate in the war effort as much as men. For example, Helen Kim would often compare women`s roles to that of men`s: "Although the pupils of Ewha should also take the glorious road towards the camp gate like (our) peninsula pupils will, the only reason why we cannot do so is because we are women." 46 Notice that women were "not allowed" to participate. In other words, she argued that women should not remain as mere spectators but as equally active participants of war, like men. She expresses this similar sentiment in another article published in 1939. She said, "I find it unfortunate that men are able to do many activities while women's activities are delayed." 47

In this particular article, she goes on to criticize men and their lack of interest in women's issues. She believed that men and women should work toward naisen ittai together. ${ }^{48}$ To new women like Helen Kim, naisen ittai policy became an opportunity to argue that women were qualified to provide service for the nation and that "men and women could collaborate, trust, and understand each other to solve problems."

46 Helen Kim, “Chingbyŏngjewa pandoyŏsŏngŭi kago,” Shinshidae, December, 1942. 47 Helen Kim, "Puindŭlkkiriŭi aejŏnggwa ihae," Tongyangjigwang, June 2, 1939, 221. 48 Kim, "Puindŭlkkiriŭi aejŏnggwa ihae." 
As the war expanded, it became increasingly arduous for feminists to push for women's rights agendas. Japan was becoming more and more militaristic, and like everything else, it demanded absolute loyalty from women toward Japan's imperialist ambitions. Many Japanese feminists had to either completely surrender to Japan's wishes or devise a way to promote women's rights within the volatile social circumstances they were placed in. Some feminists decided to withdraw from the women's rights movement altogether. Also, the Japanese government did not hesitate to censor socialist women through arrests and imprisonment, which made it more and more difficult for women's rights activists to freely express themselves. Although organizations such as Women's Suffrage League (WSL) continued the suffrage movement, with increasing surveillance and the imminent threat of an expanding war, they began to regard women's suffrage as "unattainable in an ever more serious national emergency." ${ }^{, 50}$ Instead, WSL strategically focused on community-based activism. However, suffragists had to comprise their position at times and cooperate and collaborate with other organizations that were under the government's control. ${ }^{51}$

For Korean women, the act of supporting the war indeed reflected these women responding positively to Japan's strategy to utilize the female population to continue the notorious war; however, these new women also attempted to navigate this opportunity to elevate the woman's role in Chosŏn society; naisen ittai and "Good Wife, Wise Mother" were not limited to enforcing women's biological duty to beget and raise imperial subjects. Many women, especially women educators, utilized these ideologies to challenge status of women in Chosŏn society. In addition to her lifelong calling to advocate women`s rights, Helen Kim also had another lifelong passion that she was committed to, which complicated the issue

49 Ko Myŏngcha, “Atarashii fujin no michi," Tongyangjigwang June 2, 1939, 223.

50 Taeko Shibahara, Japanese Women and the Transnational Feminist Movement before World War II (Tokyo: Temple University Press, 2014), 110.

51 Shibahara, Japanese Women, 110. 
of the nature of her collaboration-Ewha.

\section{Helen Kim's Legacy, Ewha}

Except for her stay in America to further her studies, Helen Kim's childhood and her adulthood were spent entirely in Ewha. An American Methodist Missionary, Mary F. Scranton, established Ewha in 1886 with only a single student. After liberation, it became the first women`s university in Korea, and it is still known as one of the most prestigious women's universities in Korea, showcasing prominent female scholars in various fields every year. Although Helen Kim could not afford an education, she was able to remain in school by receiving a full scholarship. As an adult, she worked as a teacher at Ewha for decades. She envisioned Ewha as fostering and equipping women to assume roles beyond another mouth to feed or another way to have economic gain since selling women into slavery and prostitution was a common practice in Chosŏn, especially in the countryside where families often struggled to make ends meet.

In her biography, she argues that she was forced to collaborate with the Japanese to protect Ewha from Japan. The reliability of her words is questionable, since there are no accounts to confirm the forced nature of collaboration. In addition, this biography was initially published in 1965, seventeen years after liberation, which causes us to wonder whether she used this book to excuse herself from all the ch'in' $i l$ accusations she received after the war. Although we can never be certain whether she was coerced into collaboration (if she was and to what extent), this biography provides a glimpse into the difficulties Ewha faced during the 1940s.

Ewha was the first women's education institution built in Chosŏn, where girls were allowed to receive an education beyond their means. Helen Kim, as an alumnus and as a teacher and later as the first Korean female principle of Ewha, was intimately involved in Ewha's growth during the colonial era. In her biography, she briefly mentions the reason she was never involved in Korean independence movements. She describes how many distinguished members of various independence movements 
asked her to join their cause, which seems probable since Helen Kim was one of the few women who was qualified enough to study abroad during the time when the United States served as a hub for Korean nationalists. Although these members persisted, she apparently declined the offer. In her biography, she says:

I believe what I have to do is different. I believe what you are doing is great and it has worth but everyone has a different role to play. I want to go back to Chosŏn. I want to work in Chosŏn. I believe what I can do is help people escape ignorance and teach them what I have learned."

The long-term financial support from foreign missionaries came to a halt due to the exacerbated relationship between Japan and the United States as the war continued to intensify after 1937. By 1942, all the missionaries were forced to return home. Although teachers and students began to abandon the schools out of fear or hesitation, Helen Kim did not consider closing the school an option. She states in her biography that, "even if she was the only to be left in school, she was willing to protect Ewha." ${ }^{, 53}$ By April of 1944, the colonial government had taken control of YeonHee Professional School, (Yonsei) which is next to Ewha. However, Ewha remained under the management of Helen Kim.

Helen Kim is often criticized for collaborating with the Japanese rather than closing the school. According to the nationalists' understanding of the colonial era, she should have closed the school to rebel against the colonial government's growing pervasiveness. Once again, this accusation is simply based on the assumption that what constitutes a patriotic act equals being part of the Korean independence movement and waging guerilla wars against Japan. However, it precariously simplifies the relation

52 Helen Kim, Kŭ pitsogŭi ch'agŭn saengmyŏng (Seoul: Ewha Womans University Press, 1999), 108.

53 Kim, Kü pitsogŭi ch'agŭn saengmyŏng, 108. 
between women`s identity and minchokchuŭi (ethnic nationalism). Most women were born into poverty, abuse, and discrimination. Even as a socalled elite woman, Helen Kim was often jeered by fellow male intellectuals, who believed that women should not have equal footing as men in all parts of society. Under this double bondage of patriarchy and imperialism, Helen Kim, a new woman of the colonial era, valued furthering education for women over being actively involved in the resistance movement.

Many of the pioneers in Korea's modern education have been criticized as being pro-Japanese (thus a traitor). In fact, there was hardly anyone with status, influence, and responsibility who decided to not "betray" Chosŏn. Many principals of schools (especially in higher education) collaborated with the Japanese to some degree. The overwhelming presence of ch'in'il'pa in the education scene makes one wonder if it was even possible to resist collaborating with the Japanese at all.

War Propaganda and Involvement in Inscription

The more controversial allegation involves Helen Kim's involvement in encouraging men and women to participate in Japan's war efforts. Initially, the colonial government hesitated at the idea of enlisting Korean men in the Japanese army. They were suspicious of Koreans' loyalty toward the army. However, with a growing demand for more soldiers, Japan did not have an alternative solution. In an effort to increase the number of enlisted soldiers, the Government General of Korea devised strategies to not only enforce enlistment but to also use propaganda to motivate the colonial subjects to participate in war efforts in every possible way.

However, the general resentment against her collaboration is most likely based upon a misunderstanding of the word chŏngshindae (women's volunteer corps). It is very interesting that when you translate the world chŏngshindae into English in a Korean dictionary, the word comfort 
women is used. ${ }^{54}$ However, when you translate the Japanese word joshiteishintai into English, it is translated as "women's volunteer corps" or "groups of young female workers organized on Japanese territory during WWII." M5 Many scholars have cautioned that the term chongshindae should not be used interchangeably with the term wianbu. This indicates that Koreans generally perceive comfort women to be identical to chongshindae even though the term chongshindae (which is a direct translation of the Japanese term teishintai) encompasses many different activities in the war efforts of imperial Japan. Sarah Soh addresses this discrepancy in her work The Comfort Women: Sexual Violence and Postcolonial Memory in Korea and Japan. ${ }^{56}$ Most comfort women were recruited through a middleman, who often deceived women by offering a job and a place to stay. Chŏngshindae, however, were part of Japan's official effort to recruit female laborers to support the ongoing war. The purpose of recruiting chŏnshindae was entirely different from that of the comfort women. Chongshindae were recruited through official announcements, unlike the women who had to "comfort" the soldiers; many of these women were often alone and were tricked or bribed into forced prostitution. ${ }^{57}$ However, the term chongshindae has been used interchangeably with the term wianbu in South Korea's nationalist historiography, which has resulted in a perversion and oversimplification of a variety of female wartime activities. This gives us the impression that most Korean women were officially recruited and forced into sexual slavery as comfort women. This gross oversimplification hinders us from understanding the lives of

54 "Naver English Dictionary," accessed December 24, 2015, http://endic.naver.co $\mathrm{m} /$ search.nhn?sLn=kr\&isOnlyViewEE=N\&query=정신대.

55 "Weblio English-Japanese Dictionary," accessed December 24, 2015, http://ejj e.weblio.jp/content/\%E5\%A5\%B3\%E5\%AD\%90\%E6\%8C\%BA\%E8\%BA\%AB $\%$ E9\%9A\%8.

56 Chunghee Sarah Soh, The Comfort Women, 57.

57 Yuha Park, Chegugŭi Wianbu (Comport Women of the Empire) (Seoul: Ppuriwa Ip'ari, 2015), 47. 
Chosŏn women and their interactions with society during this time, silencing the complexity of the identities that women had to embrace.

When we separate chongshindae from wianbu, we are finally able to consider the issue of collaboration. Many women's rights activists and educators indeed encouraged women to participate in war efforts in various ways, from being frugal with household items to willingly sending off their sons to the battlefield. First of all, there is a need to further research whether these propaganda activities instigated Koreans to participate in the war. Secondly, considering (as addressed before) that Japan was the official authority in Korean society and considering that overseas independence movements had failed continuously, what other viable options did Koreans have? Could Japan winning the war and Koreans stepping up to be the "leader" of Asia seem more plausible than fighting for independence? If so, could we give a verdict of treason? What makes this issue more challenging is that, by only naming few collaborators, the nationalist historiography has ostracized the issue of collaboration into a unique phenomenon. For example, we are quick to condemn these women for collaborating with the Japanese to pursue women's rights, whilst overlooking many Koreans, male Koreans, such as the myöngjang (head of the township), who visited and persuaded poor families to send their daughters to work in Japan (one wonders whether many people actually knew the fate waiting for these women). In many cases, "Koreans actually outnumbered civilian Japanese among those seeking profit by human trafficking, forcing prostitution and sexual slavery upon young female compatriots." 58

\section{Conclusion}

From 1937 to 1945, people in Chosŏn were confronted with conflicts they did not volunteer for. For the elites, many were burdened with dif-

58 Chunghee Sarah Soh, The Comfort Women, 140. 
ferent opinions of what would be best for Chosŏn. For some, this involved collaborating with the Japanese in various degrees. This does not negate the fact that Japan's colonial subjects, including Koreans and many others conquered throughout the war, had to experience the brutality and the barbarity of the war. Many women in these territories were forced or manipulated into becoming comfort women for Japanese soldiers. Many families in the colonies witnessed their sons being torn away from them, forced to risk their lives to serve Japan's frantic attempt to continue the war. Many were coerced into forced labor in foreign lands, and many never had the opportunity to return home. As the war raged on, life in Chosŏn, and the entire Japanese empire, became harsher and harsher.

The nationalist historiography gives us no room to wonder about the difficulties for an individual trying to navigate and survive in this sort of volatile society. However, considering the small number of people who were actually involved in resistance activities, we have to assume that the general population was destined to struggle in the gray areas, where what they were fighting against and for often became murky and obscured.

Helen Kim's multiple-layered identities as a new woman, educator, and a collaborator help us see how the issue of collaboration can be dauntingly complex. Looking into Helen Kim's life helps observers see that her life was not dictated by a simple equation of betraying her people to advance women's rights. As a colonial subject, who was labeled as being of an inferior gender, Helen Kim and many other women were doubly bounded by imperialism and the patriarchal traditions of Chosŏn society. Nationalist historiography has a tendency to overlook this aspect, and by doing so, it (subconsciously) conspires with imperialism to exclude or oppress women. Not only that, it partakes in concealing the systematic abuse against women. ${ }^{59}$ Ultimately, Helen Kim chose education as a tool to battle oppressive traditions and customs of patriarchy, where both Jap-

59 Hyŏkpŏm Kwŏn, Minjokchuŭi nŭn choeag in'ga (Nationalism is a Crime?) (Seoul: Arop'a, 2014), 150. 
anese men and Korean men were co-oppressors.

When we retrospectively impose the idea that loyalty to one's ethnic group should be prioritized above all else, we are no longer capable of seeing the complex nature of collaboration, especially in the colonial context. For her and many others, collaboration with the Japanese remained in the gray areas, where the line between collaboration and resistance became blurred, and her loyalties and priorities shifted with time.

Certainly, we have witnessed the limitations of nationalist historiography to explore the issue of collaboration. Furthermore, we perhaps need to also take into consideration the development of Chosonn under Japanese rule to fully understand why many Koreans chose to collaborate with the so-called enemy over the thirty-five year period.

\section{References}

1. Brody, J. Kenneth. The Trial of Pierre Laval: Defining Treason, Collaboration and Patriotism in World War II France. New Brunswick: Transaction Publishers, 2010.

2. Brook, Timothy. Collaboration: Japanese Agents and Local Elites in Wartime China. Cambridge: Harvard University Press, 2005.

3. Chin, Chŏngwŏn. Higashiasia no ryousaikenboron: tsukurareta dentou. Tokyo: Keisoshobo, 2006.

4. Earhart, David C., Certain Victory: Images of World War II in the Japanese Media. New York: M.E. Sharpe, 2008.

5. Hirschfeld, Gerhard and Marsh, Patrick. Collaboration in France: Politics and Culture during the Nazi Occupation, 1940-1944. Oxford: Berg, 1989.

6. Inoue, Kazue. Shokuminchi chosŏn no shinjosei. Tokyo: Akashishoten, 2013.

7. Jager, Sheila Miyoshi. "Woman and the Promise of Modernity: Signs of Love for the Nation in Korea." New Literary History 29-1 
(Winter 1998).

8. Kim, Jihwa. "Kimhwallan'gwa pagindǒkŭl chŭngsimŭro pon Ilche sidae Kidokkyo yŏsŏng Chisiginŭi 'Ch'in'ilchŏk' maengnak yŏn'gu" (A Study on the Context of 'Pro-Japanese' activities by Christian Intellectual Women under the Japanese Colonial Rule Focused on Helen Kim \& Induk Pahk). PhD diss., Ewha Womans University, 2005.

9. Kim, Sung-Eun. "Ilchesigi Kimhwallanŭi Yŏgwŏnŭisikkwa Yŏsŏnggyoyungnon”(Helen Kim's Thought of Women's Right and Korean Women's Education). Yŏksa wa Gyŏnggye (History and the Boundaries) 79 (2011).

10. Kwŏn, Hyŏkpŏm. Minjokchuŭi nŭn choeag in'ga (Nationalism is a Crime?). Seoul: Arop'a, 2014.

11. Kwon, Insook. "The New Women's Movement' in 1920s Korea: Rethinking the Relationship between Imperialism and Women." Gender \& History 10-3 (November 1998).

12. Lee, Pyeongjeon. "Shinnyŏsŏngŭi shingmin ch'ehŏmgwa chajŏnjŏk sosŏl yŏn'gu"(A Study on Modern Women's Colonial Experience and Autobiographical Novel's). Han'gugŏmunhakyŏn'gu (The Research on Korean Language and Literature) 43 (2004).

13. Mason, Michele and Helen J. S. Lee. Reading Colonial Japan: Text, Context, and Critique. Stanford, CA: Stanford UP, 2012.

14. Okuyama, Yoko. "Helen Kim's Life and Thought under the Japanese Colonialism 1918-1945.” MA diss., Yonsei University, 1989.

15. Park, Jihang. Yunch'ihoŭi Hyŏmnyŏgilgi: ŏnŭ Ch'in'il Chisiginŭi Tokpaek (Yun Ch'iho's Collaboration Diaries). Seoul: Esoope, 2008.

16. Park, Yuha. Chegugüi Wianbu (Comport Women of the Empire). Seoul: Ppuriwa Ip'ari, 2015.

17. Robinson, Michael. Cultural Nationalism in Colonial Korea. Seattle: Univ. of Washington Press, 2014.

18. Shin, Gi-Wook and Michael Robinson. eds., Colonial Modernity in Korea. Cambridge, MA: Harvard University Asia Center, 1999.

19. Sievers, Sharon L., Flowers in Salt: The Beginnings of Feminist Consciousness in Modern Japan. Stanford: Stanford University 
Press, 1983.

20. Shibahara, Taeko. Japanese Women and the Transnational Feminist Movement before World War II. Tokyo: Temple University Press, 2014.

21. Soh, Chunghee Sarah. The Comfort Women: Sexual Violence and Postcolonial Memory in Korea and Japan. Chicago: University of Chicago, 2008.

22. Ueno, Chizuko. Nationalism and Gender. Translated by Beverley Yamamoto. Melbourne: Trans Pacific, 2004.

23. Ye, Jisook. "Ilcheha Kimhwallanŭi Hwaltonggwa Taeil Hyŏmnŏk" (Kim Hwal Ran's Public Track and Her Pro-Japanese Collaboration during Colonial Korea under Imperial Japanese Reign). Han'guksaron 51 (2005).

24. Yoo, Theodore Jun. The Politics of Gender in Colonial Korea: Education, Labor, and Health, 1910-1945. Berkeley: University of California, 2008.

25. Yun, Kyŏngro et al., Ch'in'il inmyŏng sachŏn (Pro-Japanese Biographical Dictionary). Seoul: Minjok munje yŏn'guso, 2009. 
$<$ Abstract $>$

\section{Helen Kim as New Women and Collaborator: A Comprehensive Assessment of Korean Collaboration under Japanese Colonial Rule}

AhRan Ellie Bae

Although almost seventy years has passed since Korea's liberation from Japanese rule, the issue of collaboration still haunts Korea today. Attempts to resolve this issue have tended to focus attention on the traitorous actions of "collaborators" without considering the gray areas that surround their actions such as the circumstances that influenced the accused to commit their alleged traitorous acts and the intentions that drove their decisions. Helen Kim, as a "new woman" and an educator, valued the necessity of providing education for women. Yet, her efforts to realize this goal, to the contrary, forced her into actions that would later be used to construct a reputation as a Japanese collaborator. Korea's nationalist historiography has a tendency to polarize this issue by categorizing a "collaborator" as either a traitor or a patriot. However, when we take a closer look at these collaborators' lives, we discover that most collaboration happened in gray areas where it is often difficult to clearly draw a line between treason and collaboration. Helen Kim's case suggests that the issue of collaboration cannot be fully explained by nationalist historiography's framework and we must give attention to these gray areas. Through her story I hope to complicate the issue of collaboration by raising questions that address the gray areas that surround the actions of "collaborators." In doing so, I hope to challenge the nationalist historiography's propensity to oversimplify this issue and present a more nuanced understanding of it.

Keywords: Helen Kim, collaboration, pro-Japanese, ch'in'il'pa, gender, nationalism 


\section{〈국문초록〉}

\section{신여성 그리고 친일협력자로써의 김활란: 일본 식민통치 하의 조선인 친일협력에 대한 포괄적 이해를 위하여}

배아란 (릿쿄대학교 21세기사회디자인연구과 박사과정)

한국이 일본 식민통치로부터 해방된 지 거의 70 년이 지났음에도 불구하고, 친 일협력은 한국에서 여전히 중요한 문제이다. 친일협력 문제를 청산하려한 그간의 시도들은 친일협력 혐의자들로 하여금 반역적인 행위을 하게끔 한 환경과 그러한 선택을 낳은 의도와 같은 회색지대가 있다는 사실을 고려하지 않고, "친일협력자" 의 반역 행위에만 주목하는 경향이 있다. "신여성”이자 교육자인 김활란은 여성 교육을 중요하게 생각하였다. 그러나 자신의 목표를 달성하려는 그녀의 노력들은 후대에 친일협력자로써의 악명을 낳게 한 행동으로 이어졌다. 한국의 민족주의 역 사학은 “친일협력자"를 반역자 또는 애국자의 양극단으로 범주화하는 경향이 있 다. 그러나 친일협력자의 생애를 보다 상세히 관찰한다면, 우리는 대부분의 협력 행위들이 보다 분명한 반역죄와 단순한 협력 사이의 회색지대에 있음을 알 수 있 다. 김활란의 생애는 민족주의 역사학으로는 친일협력 문제를 완전히 이해할 수 없다는 것, 그리고 이와 같은 회색지대에 주의를 기울여야 한다는 것을 보여준다. 필자는 그녀의 삶을 통하여 “협력자”의 행위 주변에 있는 회색지대를 주목함으 로써 친일협력 문제의 복합성을 드러내고자 한다. 이를 통하여, 민족주의 역사학 이 친일협력 문제를 과도하게 단순화한 것에 도전하면서, 보다 미묘한 이해를 제 시할 수 있기를 바란다.

주제어: 김활란, 부역, 협력, 친일, 친일파, 젠더, 민족주의 
